\title{
SHIFTING THE LEGAL BORDERLANDS OF RULE OF LAW PROGRAMS - BRAZILIAN COOPERATION AGENCY (ABC) AND PUBLIC DEFENDERS' OFFICE IN EAST TIMOR
}

\author{
SAPNA REHEEM SHAILA ${ }^{1}$
}

\begin{abstract}
This paper gives a thicker account of the rule of law reforms initiated by Global South donors. Compared to traditional Global North donors, who take a topdown approach to the rule of law promotion, emerging donors from the Global South take an approach of mutual cooperation. Donors from the Global South are more open to accommodate legal pluralism, as well as take a prolonged approach of assistance. They are willing to build networks with local stakeholders drawing on their post-colonial and development trajectories. Using a case study of Brazilian legal assistance within the Public Defenders' Office through the ABC in East Timor, the author shows how non-traditional international donors has subverted the traditional model of 'rule of law' assistance. This paper bridges the gap between the scholarship on the South- South cooperation within development studies and the legal scholarship on law and development- focusing on the rule of law reforms. Using empirical data, the paper demonstrates the distinctive approaches undertaken by the Brazilian international actors within East Timor. Further, it poses questions on the universality of the rule of law reforms advocated by traditional donors by demonstrating the emergence of peripheral interests from the engagement of donors from the Global South.
\end{abstract}

KEYWORDS: Rule of Law programs; Legal Pluralism; South- South Cooperation; Brazilian Cooperation Agency (ABC); Public Defenders' Office.

\footnotetext{
${ }^{1} \mathrm{PhD}$. Candidate in Law, King's College, University of London. I am grateful to Mr. Bertanizo Ghurro for the research assistance, and valuable insights provided in Dili, East Timor from March - August 2018. I would also like to extend my gratitude to the two peer reviewers whose valuable comments have enriched this paper. Mistakes if any, are my own. E-mail: sapna.reheem_shaila@kcl.ac.uk.
} 


\section{INTRODUCTION}

This paper provides a thicker narrative to observations on how the engagement of Global South donors moved away from traditional development aid assistance pattern. Focusing on the rule of law (RoL) reforms, the author shows how Global South donors pushed the "legal' borderlands' of legal technical assistance (LTA) ${ }^{2}$ or widely known as the rule of law promotion. A review of scholarship on the rule of law indicates formalisation of state-based laws, and corresponding institutions as the primary modus operandi of RoL donors. Quantification of nation states' realities through indicators like rule of law index and fragility state index has furthered the movement towards creating a uniform 'global legality'. ${ }^{3}$ Since the primary actors of rule of law reforms emerge from the Global North- it is not surprising that the common world legal frame is often copied and made similar to that found within the donor countries.

A few states that fell within the peripheries of development discoursescategorised as "developing" or as "receivers" of aid from the traditional donors have emerged as the new donors (referred here as the Global South donors). The engagement of new donors like India, Brazil, South Africa (IBSA), China, Japan, Korea, Middle Eastern countries diverges from the practices of the traditional donors. They challenge the neoliberal approach to development assistance. ${ }^{4}$ The proliferation of donors from the Global South has urged traditional donors to point out how the emerging donors do not adhere to the principles of the Development Assistance Committee (DAC) of the Organisation for Economic Co-operation and Development (OECD) and are unwilling to follow traditional rules of international aid assistance- ${ }^{5}$ terming it as "rogue aid". ${ }^{6}$ Unlike the traditional donors, the emerging actors from the Global South show willingness to reflect on their historiesas a post-colonial state ( in the case of India, Brazil, South Africa), or of having relatively recent experiences with authoritarian political systems ( as in Brazil, China, Russia, South Africa, South Korea and Turkey), or as opponents of neoliberal or capitalist order in their past economic policies(Brazil, India and China), or even as

2 Julio Faundez, 'Legal Technical Assistance' in Julio Faundez (ed.), Good Government and Law: Legal Institutional Reform in Developing Countries (Palgrave Macmillan UK 1997), p. 1-24.

3 Elizabeth Boyle and John Meyer, 'Modern law as a Secularised and Global Model: Implications for the Sociology of Law', (1998) 49 (3) Soziale Welt 213.

${ }^{4}$ Oliver P. Richmond and Ioannis Tellidis, 'Emerging Actors in International Peacebuilding and Statebuilding: Status Quo or Critical States?', (2014) 20(4) Global Governance 563.

${ }^{5}$ Ibid. Moises Naim, 'Rogue Aid', (Foreign Policy,
https://foreignpolicy.com/2009/10/15/rogue-aid/ accessed 30 May 2019. 
countries that are subjected to external conditionality by the traditional donors. ${ }^{7}$ Thus, sitting on the borders of international political order, 8 their presence has shifted the boundaries of international development assistance. Since these emerging donors highlight uniqueness of their historical, social, political and cultural experiences as part of their development discourse this author observes that it has shifted the praxis within LTA as well (which will be demonstrated through a case study).

The article will develop in two parts. In Part I, building on existing scholarship on international development, it will be argued that the traditional mode of the rule of law reforms follow a model sourced primarily from the Global North. Critical scholarship emerging post 2000 evaluating legal reforms by the traditional donors as 'technocratic', with a 'top-down' approach ${ }^{9}$ will be contrasted with the entry of the Global South partners. In Part 2 of the paper, focusing on Brazil's technical cooperation in East Timor through the Public Defenders' Office the author demonstrates how Brazilian engagements within the country have assisted in bringing local interests to the core that were otherwise pushed to the peripheries by mainstream rule of law programs. The author argues that the strategy engaged by the non-traditional donors like Brazil embraces peripheral interests that are often overlooked by the traditional donors.

\section{METHODS OF DATA COLLECTION}

The data utilised for the paper is collected as part of a broader research project studying the role of international development donors strengthening the rule of law projects in East Timor. The data was collected by the author during FebruaryAugust 2018. For the research, semi-structured interviews with 56 participants-local and international involved with the justice sector development in East Timor were carried out. The theme of comparisons between the Global South and the traditional donors emerged during transcription and analysis of interview data. Within the justice sector in East Timor, interview participants pointed out differences in strategies and engagements by various donors- and in particular between Portuguese

${ }^{7}$ Ibid.

${ }^{8}$ One could argue that China's economy is the fastest growing, and Brazil has the highest growing economy within Latin America- therefore they play an important role in the international relations and politics. The contributions from postcolonial scholars and development scholars show how the narrative and discourses on "Global South" have always distinguished the states from the economically endowed states of the Global North.

${ }^{9}$ Mark Sedra, Security Reform in Conflict- Affected Countries: The Evolution of a Model (Routledge 2017), p. $29-42$. 
and Brazilian technical assistance (TA). Japan (through JICA), and Korea (through KOICA) were the other Global south donors within the justice sector in East Timor. Since JICA and KOICA's involvement were limited in comparison with the Portuguese and Brazilian TA within the justice sector, the author has consciously focused on the Brazilian Cooperation Agency and its influence within the Public Defenders' Office. The data relied here at best can provide a thicker description from the field on how non-traditional donors engage in mainstream rule of law reforms. This is also a limitation with the paper's claims as it does not aim to theorise on the south- south cooperation in general. Rather it provides an opportunity to reflect on the engagement of non-traditional donors from the global south and the varied possibilities and power dynamics it set in motion as a result.

Similar to any qualitative research, the interview data collected at times gave contradictory observations on the homogeneity amongst international development actors. To ensure credibility to claims made in this paper, triangulation of data through observations ${ }^{10}$ on the field and focus group discussions were relied..$^{11}$ Most of the interviews were conducted in Tetum or English, and majority of the actors used Tetum, English or Portuguese interchangeably during the meetings. A local research assistant assisted in translations. Wherever possible the author has used direct quotes from the participants, when the interviewees used Tetum/ Portuguesethe author has relied on the translated and paraphrased versions of the statements. The observations utilised in the paper also draws from a seminar organised by East Timor's Ministry of Justice and Public Defenders Office in collaboration with UNDP and the ABC. The topic for the seminar was 'Public Defenders in a democratic state: An Intercultural view of the right to Access to Justice in East Timor.' ${ }^{12}$

\section{PART I}

The author draws from existing academic scholarship within international development studies which emphasise a 'top-down' development assistance

\footnotetext{
${ }^{10}$ Deacon et a. al. 1998, ' Collision or Collusion? A discussion of the Unplanned Triangulation of Quantitative and Qualitative Research Methods' (1998) 1 International Journal of Social Research Methodology 47; Alan Bryman, Social Research Methods ( OUP 2012), p. 392.

${ }^{11}$ Informational interviews primarily carried between Dec 2016- Jan 2018; and actual fieldwork from March- August 2018.

12 The seminar was organized on $16^{\text {th }}$ March 2018 at the Ministry of Justice in Dili, East Timor. The areas covered by the seminar included 'Training of the Judicial Actors and the Legal Training Centre: Successes and Vulnerabilities'; Interactions between the formal and traditional justice system: possibilities to reform family law; Between the traditional and the Formal: The Cultural Specificities of Timor Leste and the Possibilities of Acting of the Public Defender's Office.
}

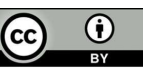


provided by traditional donors. Scholars observe how the traditional aid assistance follow a liberal model, with an emphasis on state-based laws and pre-eminence of laws and institutions found within the Global North. ${ }^{13}$ In contrast to this traditional approach scholars studying South- South development partners observe that they have emerged with a different approach to the rule of law programs ${ }^{14}$ emphasising on 'collaboration' and 'tolerance' towards legal pluralism and articulating local interests. This part demonstrates how the conventional mode of operation of LTA by traditional donors focused on establishing state-based formal laws and institutions legitimated through local elites and instituting institutions and laws that are 'copypasted' on a best practice framework from the donor countries.

\section{A UNIVERSAl LeGAL ORDER?}

Under the umbrella of the rule of law reforms, laws and legal institutions are exported to fragile and transitional states. A Working Paper from the World Bank argues, ${ }^{15}$ strengthening the rule of law in post- conflict, transitional or fragile states has mainly four underpinning reasons. They are i) economic development : a state needs to follow rule of law for predictable and enforceable laws ii)democratisation: that it needs provisions for the protection of human rights and mechanisms to hold governments iii) poverty reduction: as the poor suffer more crime and a state following rule of law provides avenues for access to justice iv) peace building: as an issue of transitional justice through creation of courts to resolve conflict, and writing constitutions and legislations to remove sources of conflict and injustices to avert future conflicts. Thus, the end goals of the RoL reforms focus on strengthening States through formal institutional building. Humphreys term the whole enterprise as a 'theatre' of the rule of law' criticising the objectives of spreading the value globallyinformed through the lens of the Western Nations' experiences. He argues that 'the rule of law promotion' has become the perfunctory term for various institutions like the World Bank, the United Nations or the USAID making it synonymous with

\footnotetext{
13Roland Paris, At War's End (CUP 2004); Simon Chetserman, You, The People: The United Nations, Transitional Administration, and State-Building ( OUP 2004); David Chandler, Empire in Denial: The Politics of State -Building (Pluto Press 2006).

${ }^{14}$ Cristina Yumi Aoki Inoue and Alcides Costa Vaz, 'Brazil as ' Southern Donor': Beyond Hierarchy and National Interests in Development Cooperation?', (2013) 24 (4) Cambridge Review Of International Affairs 507; Paolo de Renzio and Jurek Seifert, ' South- South Cooperation and the Future of Development Assistance: Mapping Actors and Options', (2014 ) 35 (10) Third World Quarterly 1860.

${ }^{15}$ Kirsti Samuels, 'Rule of Law Reform in Post- Conflict Countries: Operational Initiatives and Lessons Learnt', (2006, Social Development Papers: Conflict Prevention and Reconstruction Paper No. 37).
} 
creating institutions that are seen fundamental to promote democracy and a free market economy. ${ }^{16}$ According to Humphreys, the project has become a measure to ensure that all public acts follow a positive law, with a focus on procedures which serves as the "normative desideratum" against which to compare and challenge existing laws and institutions. ${ }^{17}$ Through the incorporation of multilateral organisations like the UN, EU, World Bank, as well as the bilateral donors like the USAID, GiZ, (Germany), DFID etc. the export of the rule of law values has become a global project.

With the end of the Cold War, Roberson argues that a single international order which was inspired by the Western state forms and its rules, customs and habits were incorporated to include the "periphery" into a single international order 18 , under the value of 'rule of law' promotion. Bellamy and Williams write that projects like the RoL date back to antiquity; political communities have provided mini-lateral agreements to support peace and stability for other political communities. ${ }^{19}$ They observe that this practice was institutionalised in the twentieth century through the establishment of League of Nations, subsequently followed by the United Nations, Bretton Wood institutions to name a few. ${ }^{20}$ These newly constituted institutional structures at the time provided responsibilities and assignments for the Western European nations which " marked a clear hierarchy in the international society" with these nations as sources of legal exports and the others as recipients whose legal orders that had to be altered.

The practice of exportation of procedures and legal institutions from especially countries within the Global North (sometimes even copy-pasted by the transitional

\footnotetext{
16 See Thomas Carothers 'The Rule of law Revival', (1998) 77 (2) Foreign Affairs 95. For an alternative take on this see Jothie Rajah- she argues how Singapore is following rule by law and not the rule of law. Thomas Carothers, 'The Rule of Law Revival' in Promoting the Rule of Law Abroad (Brookings University Press 2010); Jothie Rajah, Authoritarian Rule Of Law: Legislation, Discourse, And Legitimacy In Singapore CUP 2014).

17 Stephen Humphreys, Theatre of The Rule of Law: Transnational Legal Intervention in Theory and Practice, (CUP 2010), p. 226.

18 B.A. Roberson, 'Law, Power and The Expansion of International Society' in Cornelia Navari (ed.) Theorising International Society: English School Methods (Palgrave Macmillan 2009), p. 189.

19 Alex Bellamy and Paul Williams, Understanding Peacekeeping (Cambridge and Malden: Polity Press 2011), p. 71.

20 Ibid.

21 Ricardo Oliveira Dos Santos, ' Developing Countries and UN Peacebuilding: Opportunities and Challenges', (E- International Relations 25 February 2019) < https://www.eir.info/2019/02/25/developing-countries-and-un-peacebuilding-opportunities-and-challenges/> accessed on 30 May 2019.
} 
countries of their own accord $)^{22}$ gained the term 'legal globalisation' by some scholars. The term emphasises the flow of legal reforms which are usually driven by external pressures, with technical knowledge flowing mainly from lawyers in the Global North (Garth and Dezaley). Hammergren studying justice sector reforms in Latin America, ${ }^{23}$ and Schimmelfenning surveying RoL projects by the dominant donors ${ }^{24}$ note that lack of expertise, constraints in project schedules and funding force traditional donors to 'copy-paste' laws and institutions that are familiar to them. As a result, the traditional donors have seized hegemony over knowledge production and exportation over the rule of law reforms.

The dominance of established democracies from the Global North as exporters of law and legal institutions did not happen by chance. Anghie notes that although the 'rule of law' was not the focus per se during the colonial period, the concept of 'civilisation' through the law was widely reported during colonisation. He argues that the concept of 'civilisation' was used by colonialists to distinguish between the European and non- European states- especially concerning law and sovereignty. ${ }^{25}$ The presumption was only civilised societies created law and institutions. Therefore, for a state to be part of the international community- it needed to possess such institutions. ${ }^{26}$ The argument was extended that only a strong state with institutions that had checks and balances created laws that subscribed to the principle of the rule of law. In the nineteenth century, with the breakdown of the traditional world into sovereign states, the project of international law had to find means to convince states to follow it. International law through conventions and declarations became a binding force amongst the sovereign states. Koskenniemi for instance shows how the project on international law created a convincing myth. International law as customs that bind sovereign states, with a mission to cement connection between civilised nations that follow certain codes of sovereign conduct. This makes it unsurprising that the model transplanted primarily through international assistance projects resemble a Western or Westphalian state structure with a strong emphasis on the State, and a legal order based on the value of the rule of law sourced from the State.

22 See Volkmar Gessner and David Nelken(eds.), European Ways of Law: Towards a European Sociology of Law (Bloomsbury Publishing 2007).

${ }^{23}$ Linn Hammergren, Justice Reform and Development: Rethinking Donor Assistance to Developing and Transition Countries (Routledge 2014).

${ }^{24}$ Frank Schimmelfenning, ' A Comparison of Rule of Law Promotion Policies of Major Western Powers', in Michael Zurn et. Al (eds.), Rule of Law Dynamics ( CUP 2012), p.111.

25 Antony Anghie, Imperialism, Sovereignty And The Making Of International Law (CUP 2005), p. 56; , Martii Koskenniemi, The Gentle Civiliser Of Nations: The Rise And Fall Of International Law 1870-1960 ( CUP 2001), chapter 2.

${ }^{26}$ Anghie, ibid. p. 56. 
In this framework- State authorized law take primacy over other normative positions existing in the form of traditional/ non- state norms.

The RoL promotion has also gained prevalence as a result of increased focus on indicators like the 'rule of law index'27 or 'fragile states index' 28 that compares and ranks states on their laws, institutions, its functions and perceptions. A country that ranks lower gets assistance from international partners who assist in aiding the nation to rise in such evaluation by undertaking reforms. ${ }^{29}$ Merry argues various indicators have become central to global reform and global governance, 'they influence the allocation of resources, the nature of political decisions, and the assessment of which countries have bad human rights conditions' ${ }^{\prime}{ }^{30}$ In a world where every state is on their drive to derive legitimacy within the international regime as a sovereign state, indicators become a common language to articulate their varied legal experiences internationally. ${ }^{31}$ Uruena sums up that indicators become a platform for the interaction between international and domestic communities in communicating as to the extent domestic communities have adopted international legal norms. In this way indicators communicate as to how states that rank lower must 'learn', 'transform' or 'adopt' values and institute formal reforms that allow them to climb up the ladder, with the common prescription of copying legal templates from donor countries. A legal order that is cosmopolitan is encouraged, which inevitably means similar to that of established democracies( cosmopolitan legality). ${ }^{32}$ From the language of law to institutions that are adopted, states are immediately assessed for their accessibility to an international community through a common legal language and institutional logic. Under these templates non-state forms of law that exist as traditional laws fall out of the frame and become an anomaly, or at the best as an alternative system below the formal law. ${ }^{33}$ A comprehensive explanation to the scepticism of traditional law within the RoL promotions is articulated in Grenfell's

\footnotetext{
27 World Justice Project Index on the Rule of Law, see here, https://worldjusticeproject.org/ourwork/research-and-data/wjp-rule-law-index-2019> assessed on 30 May 2019

${ }_{28}$ Fund for Peace, Fragile State Index, see here https://fundforpeace.org/2019/04/10/fragile-statesindex-2019/, assessed on 30 May 2019.

${ }^{29}$ Evident in Paris Declaration asking developed nations to assist other nations financially and technically. See the Paris Declaration on Aid Effectiveness (2005) and the Accra Agenda for Action (2008).

30 Sally Merry, 'Measuring the World: Indicators, Human Rights and Global Governance', 2011 52(3) Current Anthropology 83, pp 83-95.

31 Martii Koskenniemi, 'Hegemonic Regimes' in Margaret Young(ed.) Regime Interaction in International Law: Facing Fragmentation (CUP 2012), 305- 323.

32 Boaventura de Sousa Santos and César Rodrigues-Garavito (eds.), Law and Globalisation from Below ( CUP 2005).

${ }^{33}$ See Laura Grenfell, Promoting The Rule Of Law In Post-Conflict Societies ( CUP 2013).
}

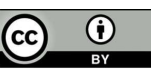


monograph. She explains the reasons as to why international partners generally have hesitated to acknowledge other legal orders. She notes that the coexistence of multiple legal orders is seen as a threat to the legitimacy of the State and its institutions. ${ }^{34}$ Further, there are concerns as to what extent traditional legal order circumscribes to human rights law or to the protection of women rights? This has consolidated the focus on institutional arrangements that are fundamental to the formal legal system, by consolidating power and legitimacy through state institutions and local elites recognised by traditional donors. Such an approach pushes other local voices, and their perspectives to the peripheries.

\section{SOUTH- SOUTH COOPERATION AND PUSHING BEYOND THE LEGAL BORDERLANDS OF THE RULE OF LAW PROMOTION}

According to OECD database documents, the major players for the transfers of legal norms and institutions originate from the Global North. ${ }^{35}$ This trend surprisingly has been broken in the recent years with the entry of non-traditional development partners like China, South Africa, India and Brazil. The rhetoric of the new entrants- who are the non-OECD donors is that their cooperation does not come with the same power dynamics as that of the traditional donors. And that the South South Cooperation group consider the process as an exchange rather than as an imposition. ${ }^{36}$ The south- south cooperation narrates that its assistance move beyond the 'donor-recipient' framework of traditional donors, to that of 'two partners' engaging with each other. ${ }^{37}$ The emphasis on a joint- cooperation gives the partners to look closely at the realities or contexts of the countries that receive assistance. The states that form the south- south cooperation highlight their colonial pasts; ;8 advertise their pluralistic societies; emphasise their distinct trajectories of economic development; and call attention to their own experiences as aid recipients. Therefore, what would be considered as 'illogical' within the framework of universal templates advocated by traditional donors is an anomaly welcomed and familiar to the nontraditional donors.

${ }^{34} \mathrm{Ibid}$, Chap 2: 'A globalized view of the rule of law and legal pluralism', pp 14- 58.

35 OECD DAC members can be seen here< https://www.oecd.org/dac/dacmembers.htm> accessed on 30 May 2019.

${ }^{36}$ Supra n. 3.

${ }^{37}$ Ibid.

${ }_{38}$ Clemens Six, 'The Rise of Postcolonial States as Donors: A Challenge to the Development Paradigm?' , (2009) 30 Third World Quarterly 1103. 
Global south partners entry to international development assistance highlighted the limitations of development assistance from Global North. Sedra gives five reasons- firstly the structure of development assistance from the Global North is criticised for being technocratic, disempowering local voices and interests. Secondly, the praxis of traditional development assistance treats the recipient states as blank pages devoid of their history and local legal culture. Such an approach disregards the traditional institutions, complex authority structures found within the recipient society by 'imposing a top-down, donor- driven approach. ${ }^{39}$ Thirdly, the liberal project is mainly advanced with strategic objectives that favour donors from the Global North rather than keeping the interests of locals in mind. Fourthly, the nature of development assistance from the global north, which marks itself independent and impartial overlook the local power dynamics. Fifthly, there are huge 'political, economic and social costs associated' as part of the liberal peace that favours the Global North. ${ }^{40}$ Further, the gap in knowledge as to how to bring change in a societywhose realities, concerns and legal culture vastly differ from the traditional donor states make it a challenging feat. Carothers succinctly describes this ${ }^{41}$

Aid providers know what endpoint they would like to help countries achieve-the Western-style, rule-oriented systems they know from their own countries. Yet, they do not really know how countries that do not have such systems attain them. That is to say, they do not know what the process of change consists of and how it might be brought about.

Thus, the rule of law export, as explained in the section above focus on form over function. As a result, it overlooks informal means of dispute resolution, local power allocation, and other interests that are marginalized as a result of the mainstream rule of law promotion.

When traditional donors have managed to gain no headway regarding successful LTA, emerging actors emphasise the comparative advantages they bring to traditional peacebuilding exercises..$^{42}$ The actors from the Global south take a varied approach by building their own concept of peacebuilding based on their identity

39 Sedra, supra n.8.

40 Ibid, pp 29-42.

41 Thomas Carothers, Promoting the Rule of Law Abroad: In Search of Knowledge (Carnegie Endowment for International Peace 2006), p. 21.

${ }^{42}$ Charles T. Call and Cedric de Coning, Rising Powers and Peacebuilding: Breaking the Mold (Palgrave Macmillan 2017), p. 244. 
and history. ${ }^{43}$ Unlike traditional donors, the new donors invest in a long term strategy as part of their engagement. These actors emphasise the importance of local ownership and believe in an egalitarian global order with no hierarchy. It means that there is more mutual respect and cultural understanding between the parties without "othering". Within the south-south partnership, there is a lesser emphasis and constraints on aspects like monitoring and evaluation which makes development assistance a less bureaucratic process. ${ }^{44}$ In a way the non- traditional donors have utilised their succession within the international community alongside their cultural diversity, legal pluralism and weak institutions highlighting these as their currencies that set them apart from the traditional donors. The relaxed structure of development assistance model of the south- south partners specifically make it easier for the actors to engage with local stakeholders over a longer period, gauging and stock taking the legal culture/cultures that are situated within the partner society. Therefore, their flexibility to consider traditional laws as an instrument to further the rule of law could be read as a strategy to gain a foothold and a piecemeal of the international development sector. But the unintended consequence of such a strategy has assisted in bringing forth peripheral local interests and non-state modes of law within the broader framework of rule of law reforms, thus pushing the legal borderlands of what constitutes legal assistance in ordinary circumstances.

\section{PART II}

In the following part drawing from empirical evidence within East Timor, I argue how the rhetoric and narrative of a "cooperative" technical assistance by the ABC paved space for articulating marginalised local interests. This is explored through two issues raised by the local stakeholders during the semi-structured interviews- i) the adoption of Portuguese as the legal language creating an elite legal system ii) and the tensions between the traditional and the formal legal system.

\section{BRAZILIAN INTERNATIONAL COOPERATION}

International development scholarship notes that Brazil's engagements within the sector is young. Brazil's foreign policy of non-intervention and preservation of national sovereignty kept the country away from engaging in international development for an extended period of time. In 1996, twenty-two middle income countries were backed by the United Nations High Committee as part of the South-

${ }^{43}$ Ibid.

${ }_{44}$ Call and Coning, supra n.41, p. 256- 262.

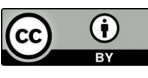


South cooperation. One of the Brazilian diplomats commented on the move as "those emerging and "graduated" countries (..) were assigned with a new role: being the protagonists of South- South Cooperation." 45

The Brazilian development assistance through the Brazilian Cooperation Agency (known as the $A B C$ ) expressed to follow a different model from other international development agencies. Brazils' strategy within international development was conceptualised as horizontal and non-hierarchical- through exchanges of knowledge, expertise, resources with partner nations. An approach distinct from the one-way model followed within the paradigms of North-South cooperation. ABC emphasised that their model was of 'cooperation', and terms like 'aid' was rejected as Brazilian policymakers underscored horizontal relations between Brazil and its partner aid recipient states. ${ }^{46}$ Thus the official narrative stuck to the version of $A B C^{\prime} s$ engagements as not for furthering economic or political interests but for providing solidarity. ${ }^{47}$ Within this narrative, Brazil as a cooperating South- South donor recognised the expansive role of the aid recipient society in contributing to knowledge production and independence in deciding the direction of the reforms. This approach varied from what Garth and Dezaley observe as the promotion of legal orthodoxy by the lawyers and economists from the Global North. ${ }^{48}$

An example of Brazil's unique approach to the rule of law promotion is shown through its engagements in Guinea- Bissau. Abdenur and de Souza Neto argue that after the civil war within Guinea-Bissau, many international actors extended support to assist the country back to stability. ${ }^{49}$ The international community stressed on the

\footnotetext{
45 Iglesias Puente, A cooperação técnica horizontal brasileira como instrumento de políticaexterna: a evolução da técnica com países em desenvolvimento-CTPD-no período1995-2005 (Funag: 2010) p. 83 quoted in IC Leite et.al. , 'Brazilian South-South Development Cooperation: The Case of the Ministry of Social Development in Africa' (2015) 27 Journal of International Development 1446,p.1449.

${ }^{46}$ Cristina Yumi Inoue and Alcides Costa Vaz, 'Brazil as 'Southern Donor': Beyond Hierarchy and National Interests in Development Cooperation?', (2013) 25 (4) Cambridge Review of International Affairs 507, p. 508.

47 Some scholars also argue that Brazil has also utilised its international aid for promoting its private businesses abroad. C Schläger, 'New powers for global change? Challenges for international development cooperation: the case of Brazil' ( Briefing Papers, no 3, Friedrich Ebert Stiftung, 2007) http://library.fes.de/pdf-files/iez/global/04719.pdf accessed on 30 May 2019, also Bruno Pino, 'Brazilian Cooperation: A Model under Construction for an Emerging Power', ( Real Instituto Elcano 2010) < https://www.cbd.int/financial/southsouth/brazil-cooperation.pdf> accessed on 30 May 2019.

48 Yves Dezaley and Bryant Garth, The Internationalisation of Palace Wars: Lawyers, Economists and the Contest to Transform Latin American States' (The University of Chicago Press 2002).

49 Adriana Erthal Abdenur and Danilo Marcondes de Souza Neto, 'South- South cooperation and democracy in Africa: Brazil's role in Guinea- Bissau', (2013) 5 (2) Africa Review 104.
} 
promotion of democracy and consolidating state power through legislative elections and electoral monitoring. But within the scope, the Brazilian aid was quick to observe how a "western-style elections made no difference" 50 within the country. The Brazilians were able to identify that elections will not necessarily consolidate stability within the county as power was distributed through neo-patrimonial political alliances rather than through allocation within state institutions. As a result, Brazil's cooperation within Guinea Bissau focused on supporting grassroots nation-building to curb the resurgence of violence. When the traditional donors approached the reforms in Guinea Bissau as treating problems within a "narco-state", pushing for electoral and democratic reforms to strengthen the state institutions, Brazil took a different stance. The $\mathrm{ABC}$ was hesitant to consider the narcotics problem as a simplistic one that can be erased with a strong state. Brazilian development actors' refusal to see Guinea Bissau's problem solely as a result of drug trafficking allowed it to have a "more nuanced, organic perception of the problems" that affect the country. Brazil emphasised to other international development actors to engage in structural and social development activities, rather than narrowly focusing on strengthening security for uprooting narco-trafficking. ${ }^{51}$ Development scholars congratulated $\mathrm{ABC}$ for undertaking a nuanced approach within Guinea- Bissau and diverging from other major donors on the field. ${ }^{52}$

\section{VI. 'TRANSITIONAL' STATE OF EAST TIMOR}

East Timor was the Portuguese colony from the end of sixteenth century until it declared its independence on $28^{\text {th }}$ November 1975 . Within nine days of declaration of independence from Portugal, the Indonesian army took over. Indonesia annexed East Timor as one of its provinces in 1976. The Indonesian occupation was resisted over a period of twenty-four years by the local citizenry. The local resistance (from the clandestine guerrilla front), and rigorous lobbying by Timorese diplomatic front (constituted by Timorese expatriates settled in Angola, Mozambique and Portugal) culminated into an independence referendum by the UN in 1999. This led the newly independent State of East Timor to be under the transitional administration of the UN until a Constitution was drafted, and a Government elected in 2002. Under the UN transitional administration, extensive reforms were undertaken to transform

50 Ibid.

51 Abdenur and Neto, supra n. 48.

52 Inoue and Vaz, supra n.45. Even though Brazil's initiatives within Guinea-Bissau were received optimistically some analysts argued that the Brazilian approach can be implemented with success only if it is complemented by other approaches, for a discussion on this see Silvia Roque, 'Peacebuilding in Guinea-Bissau: A Critical Approach', (2009) Norwegian Peacebuilding Centre. 
East-Timor into an ideal poster state. ${ }^{53}$ UNTAET in collaboration with other bi-lateral and multi- lateral donors initiated a project for "state-building" within the country. ${ }^{54}$ In a way the arrangement paved an easier importation of legal templates and institutions into the country. Bi-lateral donors from the USA, Australia, Portugal, Germany, Japan, Korea, Brazil, Angola and Cape Verde were involved in various justice sector projects within the country. ${ }^{55}$ Multilateral donors included the UN and the European Union. World Bank is also a significant donor within the country, but its influence on the justice sector reform is minimal compared to the other donors. ${ }^{56}$

Particularly within the judicial sector- the Lusophone nations play a significant role as the technical advisors. Silva commenting on the influence of the Lusophony donors within East Timor notes the trend as a form of postcolonial community building- similar to the commonwealth nations. ${ }^{57}$ Other commentators add that with the return of many Timorese elite expatriates from countries like Mozambique, Angola and Portugal, it was an obvious choice to resort to the Portuguese legal system. ${ }^{58}$ Therefore under UNTAET administration Portuguese was made as the official legal language, and new laws were legislated modelled on the Portuguese legal system. Amongst the Lusophony donors, Portugal plays the dominant role in providing institutional and technical support within the justice sector. The Portuguese Ministry of Justice has MoUs for assisting the Prosecution Services, the Courts and the Parliament. The Office of the Prosecutor and the Courts are structured around the Portuguese model. As a result, LTA from Portugal involve technical assistance through Portuguese judges and prosecutors within these

53 Hansjorg Strohmeyer, 'Collapse and Reconstruction of a Judicial System: The United Nations Missions in Kosovo and East Timor', (2000) 95 The American Journal of International Law 46 - calling East Timor as UN's poster child.

${ }^{54}$ It is unsurprising that many international actors are interested in gaining partnership with the country for its oil and gas reserves. This report is indicative of when the interests exceeded legitimate means of procuring information. See in detail, Mong Palatino,' East Timor Australia Spying Scandal' ( The Diplomat, 16 December 2013) < https://thediplomat.com/2013/12/east-timoraustralia-spying-scandal/> accessed on 30 May 2019.

55 Council of Coordination for Justice, Justice Sector Strategic Plan for Timor-Leste 2011- 2030 (12 February 2010). Involvement of actors from Cape Verde, Angola, Korea became evident during fieldwork and interviews. Interview with Japanese International Cooperation Agency (JICA) Participant 1 on 23 April 2018.

56 Ibid.

${ }^{57}$ Informal conversation with Dr Kelly Silva, 12 ${ }^{\text {th }}$ March 2018.

58 Highlighting the involvement of Timorese expatriates returning from Portugal and Mozambique playing an important roles as conduits for transfers of law and legislations. Informational interview with ex- adviser to the President of East Timor 25 January 2018; Informational interview with exUNDP advisor 8 December 2016. 
institutions. ${ }^{59}$ One of the interview participants observed that Sergio de Mello-a Brazilian and the first resident coordinator of UNTAET had a significant role in transplanting the Brazilian PDO office within the country. ${ }^{60}$ Brazil entered into trilateral cooperation with the UNDP and the Government of East Timor (through the Council of Coordination for the Justice Sector) to provide professional training and technical assistance to the Public Defenders' Office (PDO). The participant observed that many Portuguese actors within the sector disapproved the institution of the Public Defenders office as it was incongruent with the justice sector model in Portugal. ${ }^{61}$ This could explain why the Office of the Public Defenders is absent within the Constitution ${ }^{62}$ - which is structured to resemble the Portuguese model. One of the Portuguese legal trainers explained that the Brazilian model of PDOs in East Timor, needed urgent replacement with a legal aid structure similar to Portugal or continental Europe involving private lawyers. ${ }^{63}$ Whereas local activists were quick to defend the PDO as the only means of free legal aid service for the poor within the country. ${ }^{64}$ Such observations indicate as to how extensively form or exact replication of legal institutions are still the preferred means amongst many donors.

Legal experts from Portugal are introduced as legal technical advisers within the MoJ, Prosecutors' Office, Parliament, and the law department at National University. Through these experts, a narrative on the supremacy of the Portuguese justice system is imparted to the local counterparts. Comparisons with the Portuguese legal system was articulated through observations of Portugal as an old established state- with its

59 It should be noted that in 2014, there was a clash between the local Government and the international advisors within the Court of Appeal over a tax decision. As a result of which the Government asked the technical advisers to leave the country. Primarily Portuguese judges and advisers were affected by the decision. See Judicial System Monitoring Program, 'Dismissal of International Officials and Advisers in the Timor-Leste Judicial Sector: An Analysis of the Constitutionality, Legality, and Impact of Parliamentary Resolution No. 11/ 2014 and Government Resolutions No. 29/ 2014 and 32/ 2014', https://www.laohamutuk.org/Justice/2014/JSMPRept16Dec2014en.pdf>, accessed on 30 May 2019. At the time of data collection one Portuguese prosecutor was appointed within the Office of the Prosecutor, along with an advisor from Cape Verde. As for the courts there were no international judges sitting as advisors between 2014- mid 2018. By mid May 2018 one Portuguese judge was appointed as a Judge Inspector.

${ }^{60}$ Interview with UNDP participant no. 3 on 9 March 2018.

${ }^{61} \mathrm{Ibid}$. Similar observations were also made by MoJ Participant 2, Meeting on 5 May 2018.

62 Council of Coordination, supra n. 54.

63 Fieldnotes, 23 March 2018.

64 Asia Justice and Rights (AJAR), Laloran Justisa Program disseminating manuals and TV programs on the Practical Lessons in Human Rights. The organisation particularly highlights the role PDO and the Ombudsman Office have in protecting human rights. 
laws and institutions existing over a long period of time. For those local stakeholders comparing, their own country had a long way to go to attain the standards similar to Portugal. In the words of prospective judicial actors in the Legal Training Centre $(\text { LTC })^{65}$

Portugal is an old country unlike Timor- Leste. Their jurisprudence is rich as they have been applying the laws for many years. We can learn so much from them.... Similarly, Portuguese is a global language and there are many books already written about the law in it.

Therefore, the ideal within the justice sector is conceptualised as breaking away from the local legal order and embracing a legal order that is more cosmopolitan. But this quest is met with challenges as the local Timorese society struggles to straddle between the traditional and the newly introduced state-laws. As well to engage in a legal language that is challenging not only for the ordinary citizens but also for many local legal actors. Despite local concerns Portuguese became the official legal language. Similarly, the primary legal institutions that receive LTA mainly from Portugal emphasise on formal law over traditional system. An academic scholar based in East Timor, reflected that at the time of constitution drafting disagreements between locals (the ones who remained, and Timorese expats who returned) on the position of traditional law was common. ${ }^{66}$ Further, the decision to make Portuguese as the official language was contested by many locals ${ }^{67}$ and some international development actors. ${ }^{68}$ In this context, the Brazilian LTA took an unconventional approach. The Brazilian aid actors were able to forge alliances with the locals- whose interests and concerns were side lined, as a result of reconstituting the local legal order to a cosmopolitan one. Contrary to other donors within the sector, Brazilian technical advisers become a mouthpiece to share local narratives that were pushed to the peripheries as part of dominant LTA approaches.

\section{MAPPING THE DISTINCTIVE APPROACHES TO RULE OF LAW}

\footnotetext{
65 Focus Group discussions with trainees at the Legal Training Centre, 15 May 2018.

${ }^{66}$ Meeting with local researcher on 28 March 2018, according to the participant traditional law was included as part of the constitution at the insistence of one of the veteran members who became a political leader during the transitional period.

67 This issue is discussed more in detail below.

68 Informational interview with erstwhile UNDP East Timor adviser on 8 December 2018, mentioning how Australia particularly, and USA were promoting for English as the legal language which was shot down by the local political elites during the transition period.
} 


\section{REFORMS BY THE BRAZIL COOPERATION AgENCY (ABC)}

During data collection, it emerged that the main contention with the traditional rule of law approach was its blinkered approach of strengthening state based legal system. Traditional donors stressed about the importance of a legal language that can capture legal fictions- allowing for international influences and at the same time providing a cosmopolitan image to the state. Adherence to Portuguese as the legal language within the courts and bureaucracy was articulated to streamline TimorLeste as another member of the CPLP community. Similarly, even though traditional law was recognised within the constitution, a push to imagine the pre-eminence of state-sanctioned formal laws was widely encouraged by traditional donors. ${ }^{69}$

\section{Local Legal Language}

The language politics within East Timor is widely documented. ${ }^{70}$ The country followed Portuguese as its lingua franca until 1975. But historians note that the colonial administration never took measures for educating its colonial subjects in the language. ${ }^{71}$ After the Indonesian occupation, educational institutions and judicial institutions followed Bahasa Indonesian. When East Timor gained its political independence in 2002, with the percolation of Indonesian schools, television channels and newspaper journals majority of the population was well versed in Bahasa Indonesian. ${ }^{72}$

Under the Constitution, Tetum (one of the local languages) and Portuguese became co-official languages. Many locals still contest introduction of Portuguese as the primary official language. The decision has streamlined financial resources (primarily coming from CPLP countries) within in justice sector to spend on developing Portuguese language and its usage within the country. ${ }^{73}$ An indicative

\footnotetext{
${ }^{69}$ An example for this was highlighted during the seminar organised by UNDP, PDO and the MoJ- it was highlighted that under the new family law there is no provision to recognise the reality of distantly related young children living in households of their uncles (status similar to an adopted child) but fails to get recognition over property and other rights flowing from their relation to the patriarch of their new family. Another common example that is highlighted is the land law regarding agricultural lands and property rights vested on certain families in some areas of the country.

${ }^{70}$ Kelly Taylor-Leech, 'The Language Situation in Timor- Leste', CURRENT ISSUES IN LANGUAGE PLANNING Vol. 10 (2009)1.

${ }^{71}$ Ibid.

72 This doesn't mean that the endogenous languages died during the period. The local languages were widely spoken during the colonial as well as the Indonesian occupation period.

${ }^{73}$ Interview with CSO Participant 7, 16 May 2018.
} 
example is that legislations passed in East Timor- all are available in Portuguese, whereas Tetun versions are rarely available. ${ }^{74}$ Funds from CPLP partners cannot be utilised for translation of legislations into Tetun ${ }^{75}$ - as the aim of financial assistance is to strengthen Portuguese as the lingua franca within the state. ${ }^{76}$ Civil society members highlight the difficulties of local actors- citizens, lawyers, and activists in critically engaging with the law because of the language barrier. ${ }^{77}$ One of the academic researchers pointed out that the linguistic quagmire has splintered the local community. ${ }^{78}$

It [ using Portuguese] is a politically elite project, so that the poor and disempowered are always kept away from the law.

Portuguese technical advisers insist on the usage of Portuguese within the court rooms, legislature and in legislations ${ }^{79}$-even if it means that most local actors struggle to grapple with the nuances of law. One of the interview participants observed that this often led to situations within the legislative assembly with the elected legislative members not debating proposed legislations. ${ }^{80}$ The policy approach on legal language is immersion. Once every legal correspondence and act is in one language, it is expected that the legal system will take foothold within the society. Further, it is expected to open avenues for engaging with the expanse of legal jurisprudence emerging from Portugal and other Lusophone nations. This has led to the stigmatisation of indigenous languages leaving a social gap amongst local elites and the rest. ${ }^{81}$ Imposition of Portuguese as the legal language is met with frustration especially by young law graduates at the Legal Training Centre (LTC) and local law schools. During a focus group discussion- the graduates observed that reading legal texts in Portuguese as challenging. They articulated that often they are unable to articulate their thoughts during examinations or discuss their queries with the

${ }_{74}$ All the websites under Ministry of Justice publish their legal documents and information in Portuguese. Of 171 laws passed by the Parliament, only 13 are available in Tetun, for details on legislations passed by RDTL see here http://mj.gov.tl/jornal/?q=node/12

${ }^{75}$ MoJ Participant 2, 5 May 2018.

${ }^{76}$ Ibid; Meeting with UNDP Participant 3 on 9 March 2018.

77 Interview with JSMP 9 April 2018; Interview with MoJ Participant 2, 4 May 2018; Focus Group with trainees at the Legal Training Centre, 15 May 2018 etc.

78 Meeting with Dr. Helen Hill on 7 March 2018.

${ }^{79}$ Meeting with MoJ Participant 2, 5 May 2018.

80 Ibid.

81 See Bernard Spolsky, 'Language Policy in Portuguese Colonies and Successor States', (2018) 19 Current Issues in Language Planning 62. 
Portuguese legal trainers. ${ }^{82}$ Compared to these experiences, the local stakeholders were quick to distinguish their interactions with the Brazilian technical partners. They recounted how the Brazilian legal trainers were keen to learn the local language with even attempting to tackle the course material in Tetum. ${ }^{83}$ A Tetun language instructor at the Legal Training Centre resonated similar sentiments. The instructor noted that Brazilian colleagues were keen on learning the local language to make their interactions more meaningful with the locals. ${ }^{84}$ It is not surprising that one of the Brazilian defenders during our interview started out by emphasising that

We Brazilians have a different way of dealing with [ international development assistance]. We were not colonial powers. Maybe I am biased to say this... But I think we are more culturally sensitive. We bring our experiences... if they find it useful, they may use it. We are more submitted to the guidelines that the Timorese PDO office gives to us. But we don't impose [ emphasis added by the author] it..$^{85}$

The emphasis on the shared trajectory to statehood by the Brazilian donors assist them to position as partners who have mutual experiences rather than actors who are present on the field to 'reform' the recipient society. As one of the interviewees observed, it is a "partnership" that the ABC tries to build in East Timor. The joint seminar organised by PDO office along with MoJ and UNDP saw Brazilian academic experts, and legal actors working within the country stressing on the issues of language and prevalence of traditional law within the country. ${ }^{86}$ An interviewee with a local UNDP official highlighted the importance of the support received from the Brazilian colleagues in pushing for funds to appoint a Tetum language trainer within the Legal Training Centre, as well as two Tetun translators within the MoJ specifically for translating legislations ${ }^{87}$ in 2018. Therefore, the engagement of the Brazilian LTA drawing from their experiences within the PDO and at the Legal Training Centre gave visibility to the issue on language to the other international actors.

\footnotetext{
${ }^{82}$ Focus group discussions with trainees from LTC, 15 May 2018.

${ }^{83} \mathrm{Ibid}$, Meeting with Legal Tetun Trainer at LTC 3 April 2018.

${ }^{84}$ Meeting with Legal Tetun Trainer,3 April 2018.

${ }^{85}$ Meeting with Brazilian trainer at PDO participant 1, 26 March 2018.

${ }^{86}$ Brief and audio recordings of the seminar available on file with the author.

87 Meeting with UNDP participant no.3, 9 March 2018.
} 


\section{Traditional Law}

Under UNTAET, East Timor was designed to be a poster child of the UN. ${ }^{88}$ It meant laws and institutions that befit an ideal democratic state was integrated into the Constitutional provisions. Within this objective, traditional law, and legal customs of the Timorese society fell into the peripheries. An ex- Minister of Justice noted how the local political elites were influenced by the international community to sign and ratify international treaties and conventions. According to the exMinister, this meant that the traditional legal orders had to move way for a state based legal order. ${ }^{89}$ Even though the Timorese constitution recognise traditional law as one of the legitimate sources of law, the international community is apprehensive of it. They fear that embracing traditional law could compromise human rights standards and women's rights. Biases about how a traditional system functions in general, have created rifts. ${ }^{90}$ But Grenfell writes that for the Timorese society, this is complicated - especially when the society never had a strong relationship with state law. She argues how state- centric laws disseminated by Portugal and Indonesia, never took hold fully in East Timor during their occupation- leaving prevalence of customary law within the country. ${ }^{91}$

The reasons for the prevalence of traditional law within the local legal culture ${ }^{92}$ of East Timor is an interesting one to map. Under Portuguese rule, Hohe and Nixon observe that minimal outside interference allowed traditional systems to operate..$^{93}$ Indonesian legal system was adopted under the Indonesian occupation. As a province, East Timor became subjected to laws adopted by the national legislative council of Indonesia with only civil matters being left to be dealt at the local level. ${ }^{44}$ Babo-Soares adds the widespread perceptions of corruption of Indonesian

\footnotetext{
88 Strohmeyer, supra n.52.

${ }^{89}$ Meeting on 11 July 2018.

${ }_{90}$ Common example of a positive traditional custom within the country is 'tarabandu' especially done in relation to environment harms. See more discussion in Belun- Asia Foundation, ' Tara Bandu: Its Role and Use in Community Conflict Prevention in Timor-Leste' ( 2013), $<$ https://asiafoundation.org/resources/pdfs/TaraBanduPolicyBriefENG.pdf $>$, See also Laura Grenfell, Promoting The Rule Of Law In Post-Conflict Societies ( CUP (2013), Chap 6 and 7.

91 Grenfell, Ibid, p. 187.

92 The author acknowledges that legal culture could vary from one area to other or even with different parties depending on their area of origin. Especially in Timor- Leste, there are numerous local systems of law across the region, but they share some underlying norms based on the local customs and traditions.

93 Hohe and Nixon, Reconciling Justice 'Traditional' Law and State Judiciary in East Timor, United States Institute of Peace- Washington DC, p. 27.

94 Ibid.
} 
institutions led people to mistrust the Indonesian legal system, encouraging them to rely on traditional ways of solving disputes. ${ }^{95}$ Therefore, during the Indonesian occupation, especially state law was considered as the tool of the oppressor or as 'simply irrelevant' which was partial and condoning impunity for serious crimes against the local population. ${ }^{96}$ Under the UN Transitional Administration in East Timor (UNTAET)- for the first time, extensive legal reforms were brought into to the country. It launched competing judicial institutions(now under a Government with local ownership) to run parallel to the traditional mechanisms for resolving disputes.

A common observation by local citizens noted during the research was how the traditional system is valuable in its approach by protecting relations rather than breaking it. ${ }^{97}$ Grenfell also reiterates the point by noting that the traditional law in East Timor is not based on punishment, but rather on reparations. ${ }^{98}$ Thus based with different motivations from a state-based system. Often for development donors, the coexistence of traditional law becomes problematic on the grounds of human rights and rights of women particularly. ${ }^{99}$ Even though informal justice systems offer a wider means of accessibility, familiarity and legitimacy ${ }^{100}$ within the country- there can be serious shortcomings for specific groups to access it depending on power allocation, social and cultural factors. These are valid concerns, articulated by scholars and activists working in many different jurisdictions. Especially for domestic violence cases within the country, often cited reservations about traditional law are on the lack of women's participation within decision-making process, and the tendency to blame women. ${ }^{101}$ Therefore the international community pushed for bringing domestic violence under formal law. In 2009, a new provision on domestic violence was introduced within the Penal code. It made domestic violence a public crime, to be investigated and prosecuted by the state regardless of whether a

${ }_{95}$ Babo Soares, A Brief Overview of the Role of Customary Law in East Timor, p. 12- quoted by Grenfell, supra n. 89 .

${ }^{96}$ Amnesty International, ‘ Amnesty International Report East Timor: Justice Past, Present and Future (2004), p. 13.

${ }_{97}$ MoJ Seminar; Debates by the committee constituted to study status of traditional law within East Timor

${ }^{98}$ Grenfell, supra n.89.

${ }^{99}$ Ibid.

${ }^{100}$ Grenfell, supra n.89.

${ }^{101} \mathrm{Ibid}$, Annika Kovar, ' Approaches to Domestic Violence Against Women in Timor-Leste : A Review and Critique,'<https://www.hurights.or.jp/archives/asia-pacific/section1/pdf/9\%20\%20Approaches\%20to\%20Domestic\%20Violence\%20against\%20Women\%20in\%20Timor-Leste.pdf> accessed on 30 May 2019. 
complaint has been filed by the victim or not. ${ }^{102}$ The new law states that victims cannot request cases to be dropped. But the limitations of formal system involve lack of physical access to formal justice institutions (as there are only four district courts operating and hearing cases from the nearby district courts); ${ }^{103}$ as well as lack of substantive access to the legal system exacerbated by language barriers. Practical difficulties of adopting formal standard on domestic violence against women were highlighted by a participant from the MoJ. ${ }^{104}$ The participant observed that

In villages away from Dili [referring to the capital city], it is a different situation. Domestic violence legislation is acting contrary to the benefit of women.... NGOs push women to file complaints, and by the time the court takes up the case- their dispute would have been settled in the traditional way in majority of cases. But then the court will impose penal punishment by sending husbands to prisons. This breaks down the family.

Concerns raised by the MoJ participant was evidenced during one of the court observations undertaken by the author. A wife who filed for domestic violence in 2010 after a dispute with her husband had a pending case against him in the Dili district court. By the time the court summoned them (2018) - the couple had reconciled, and the wife wanted to abandon the case. ${ }^{105}$ Leech documenting reports of domestic violence amongst women point how Asia Foundation and UNFPA in their study found that insults, followed by slapping or twisting an arm and forced sex were the common types of violence perpetrated against women. ${ }^{106}$ Despite this, only 15 percent of Timorese claimed to have experienced domestic violence. This dichotomy of how victims name their experiences as violence or not can be explained as to what the victims consider as violence situated within their individual contexts. Similarly, how victims seek out remedies for domestic violence- especially within the rural parts, desire reparative aspects than punitive elements. This could be why traditional mechanisms are resorted prevalently even for domestic violence cases by many of the local victims.

102 UNHCHR and UNMIT, FACING THE FUTURE: PERIODIC REPORT ON HUMAN RIGHTS DEVELOPMENTS IN TIMOR-LESTE: 1 JULY 2009 - 30 JUNE 2010 (2010).

103 Lindsey Greising and Nelinho Vital, ' Legal Research in Timor-Leste', < http://www.nyulawglobal.org/globalex/Timor_Leste.html\#Courts> accessed on 30 May 2019

${ }^{104}$ Interview with MoJ Participant No.2, $5^{\text {th }}$ May 2018; also highlighted during the interview with exMinister for Justice.

${ }^{105}$ Court observation no. 2, 16 May 2018.

${ }^{106}$ Kovar, supra n.100.

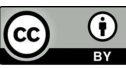


Responding to the competition between the formal and traditional law, a Portuguese trainer at the Legal Training Centre observed ${ }^{107}$

I know what my limitations are- I can only teach them [ referring to Timorese legal trainees at the centre] the law. But the values must be cultivated within families... at a young age.

The contestation between traditional law and the formal law are even observed amongst young legal graduates. During focus group discussions, the participants agreed that formal law needs adherence, but they added that such adherence will be within limits of the liurai (the traditional authority) and uma lisan (sacred house). ${ }^{108}$ Their emphasis was on the everyday prevalence of traditional law through their families and society. Whereas the Brazilian actors had a distinct approach to how they viewed traditional system within the country. ${ }^{109}$ Without dismissing traditional law completely, they were receptive of how a few traditional means of resolving disputes provided stability and maintained harmony within the society. In the seminar organised with the collaboration of Ministry of Justice and Public Defenders Office, especially violence against women was frowned upon. But the meeting recognised that there are mechanisms within the local traditional system for resolving such conflicts and warranted more attention. ${ }^{110}$ One of the Brazilian advisers during an interview noted, ${ }^{111}$

You don't have a special place to say. They have their own culture... and they want to keep it... They have the culture to reflect, resit and decide which aspects must change.

\footnotetext{
${ }^{107}$ Meeting with a Portuguese Legal Trainer, 16 April 2018.

${ }^{108}$ Focus group discussion with LTC candidates, 15 May 2018; Sara ten Brinke, ' Citizens by waiting: Timorese young adults between state politics and customary authority', CITIZENSHIP STUDIES Vol 22 (2018).

${ }^{109}$ Fieldnotes on 12 March 2018; : Seminar organized by PDO with UNDP and Agência Brasileira de Cooperação (ABC), Defensoria Pública-Geral da União do Brasil ( Public Defenders' Office- Brazil).

110 An example that was evidenced during one of the mobile court visits was a practice called fo sala where the defendant husband had to either sacrifice an animal/ gift the wife's family with money to apologise and take her back to the marital home, Mobile Court observation in Gleno on 27 July 2018.

${ }^{111}$ Interview with Brazilian trainer 2; ibid.
}

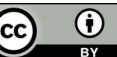


A traditional practice was evidenced during a mobile court visit in district Gleno. ${ }^{12}$ In a case for domestic violence, before the case was closed by the judges a public defender pointed out that the husband had undertaken 'fo sala'. ${ }^{113}$ ' $F o$ sala' was explained as a traditional practice to acknowledge the husband's mistakes before the wife returned to the marital home. After the proceedings, a local prosecutor explained that usually the final decision will take this into consideration by ensuring that any punishment to the husband will be reduced without breaking the family. ${ }^{114}$ The Brazilian technical advisers at the PDO office highlighted that they have no hierarchical position within their office, and that they often encourage for resolution of disputes through mediation. They saw their roles as mentors to the local actors by consulting and talking to them. ${ }^{115}$ One of the Brazilian Public Defenders articulated it in the following manner 116

Most of society lives aside from formal law. So, we can work as a bridge to make them understand what the problems are, and to convince decision makers that some traditions and customary rules may be applied in some cases [emphasis added by the author].

Thus, the Brazilian actors, emphasised their willingness to see situations when formal law could be superseded by traditional law-or sometimes even influenced by it as in the case of the mobile court proceeding accounted above. They envisioned their roles as 'bridges'- bridging knowledge between their local colleagues and themselves through discussions and extensive informal engagements. Such an approach of 'cooperation' and 'horizontal exchanges' between actors is highlighted within the 'South- South' cooperation. ${ }^{117}$

It is valuable to remember that Gacaca courts in Rwanda, for instance demonstrated how informal modes of law could rise up to exceeding demands of

\footnotetext{
112 Mobile Court observation in Gleno on 27 July 2018

${ }^{113}$ Locals described the process as involving exchange of an animal between the husband and wife's family, wherein the husband acknowledges his mistake by paying penitence to the ancestors and giving the animal to the family for taking care of the wife during their separation.

${ }^{114}$ Explanation given by a local lawyer to the research assistant on 27 July 2018.

115 Interview with Brazilian trainer 1 on 26 March 2018; Interview with Brazilian trainer 2 on 6 April 2018.

116 Interview with Brazilian trainer 1, 26 March 2018.

117 A term emphasized by the UNDP Interview participant 3 on 9 March 2018, Brazilian trainer 1, 26 March 2018.
} 
justice and thus worthwhile to be adhered. ${ }^{118}$ Widner points out the role of an informal system within a larger justice system. Within the informal system, local leaders like the tribal or clan leaders are more conflict reducing by mediating/ negotiating than a win- lose outcome as under the formal court systems. When traditional law is seen as problematic or inconsistent with the standards of human rights-the way to work with it is to evaluate it, support and reform it as part of the assistance strategy. One famous example of this is Levitt's and Merry's work on working with traditional legal systems to map whether they reflect the UDHR principles. ${ }^{119}$ In this way, the informal and traditional law that are considered outside the borders or as an anomaly can work in parallel with the formal system.

\section{CONCLUSION}

Drawing on the example of the Brazilian LTA at the PDO office within East Timor, the paper demonstrated how the Brazilian technical advisors formed linkages with the local stakeholders whose interests were side-lined during the strive for building an ideal justice sector. The involvement of Brazilian Cooperation within East Timor indicates how the South-South Cooperation partners are bolder to traverse beyond global templates. The Brazilian LTA pushed the borders of the rule of law reforms by providing collaborating spaces with the recipient stakeholders. There is acceptance and tolerance portrayed by these actors to hybrid systems, rather than imposing an 'ideal' and strict adherence to formal templates. They narrate how their lived experiences as part of a post- colonial state, or a country that slowly rose to economic prosperity and democracy resonate with that of East Timor's struggle to build its influence within the international community. In the context of East Timor, engagements from Brazilian actors have helped to provide a platform for the local actors to articulate the limitations they face with the new legal system. Especially tapping on discontents of local actors regarding the legal language, and competition of traditional system with the newly introduced formal law- they are one of the few international partners to articulate these issues within the justice sector. One could argue that the institutional structure of Brazilian assistance provides the actors with more flexibility and space to engage and interact with local actors. Further supporting the PDO gives it an advantageous position to articulate peripheral local

\footnotetext{
118 Though it should be noted that at the same time gacaca courts were criticized from some levels for procedural fairness and lack of legal representation for the accused.

119 Peggy Levitt and Sally Merry, 'making Women's Human Rights in the Vernacular: Navigating the Culture/ Rights Divide' in Dorothy Hodgson (ed.), Gender and Culture at the Limit of Rights (University of Pennsylvania Press 2011), p.81.
} 
interests. However, one could counter-argue that the concerns on access to law affect every local actor, thus signifying the importance of problematising adoption of Portuguese as the legal language. Therefore, it is only fair to observe that the Brazilian actors were able to move beyond the limitations of the traditional rule of law praxis within East Timor.

Brazil's involvement in articulating the concerns of the local stakeholders have won over the hearts of their Timorese colleagues. It is worthwhile to remember that within the context of Brazilian Cooperation in East Timor it may be true that their engagements brought local concerns/ interests that were pushed to the peripheries to the fore. But this may not be the case in other settings. In other settings, moving forward to gain a foothold within the development sector by allying with local stakeholders who are in the peripheries may not necessarily bring positive outcomes. Therefore, every setting and involvement may need careful empirical analysis. In Timor-Leste's context, the initiatives undertaken on the model of south- south cooperation seemed to have worked, but this may not be the case in other contexts. Depending on who constitutes the local interests, and what interests are picked up by the non-traditional donors to establish local linkages are all crucial units that need to be analysed.

\section{REFERENCES}

\section{Books}

Alex Bellamy and Paul Williams, Understanding Peacekeeping (Cambridge and Malden: Polity Press 2011).

Antony Anghie, Imperialism, Sovereignty and The Making Of International Law (CUP 2005).

B.A. Roberson, 'Law, Power and The Expansion of International Society' in Cornelia Navari (ed.) Theorising International Society: English School Methods (Palgrave Macmillan 2009).

Charles T. Call and Cedric de Coning, Rising Powers and Peacebuilding: Breaking the Mold (Palgrave Macmillan 2017).

Jothie Rajah, Authoritarian Rule of Law: Legislation, Discourse, And Legitimacy in Singapore (CUP 2014). 
SHIFTING THE LEGAL BORDERLANDS OF RULE OF LAW PROGRAMS - BRAZILIAN COOPERATION AgENCY (ABC) AND PuBlic DEFENDERS' OFFICE IN EAST TIMOR

Julio Faundez, 'Legal Technical Assistance' in Julio Faundez (ed.), Good Government and Law: Legal Institutional Reform in Developing Countries (Palgrave Macmillan UK 1997).

Laura Grenfell, Promoting The Rule Of Law In Post-Conflict Societies (CUP 2013).

Linn Hammergren, Justice Reform and Development: Rethinking Donor Assistance to Developing and Transition Countries (Routledge 2014).

Mark Sedra, Security Reform in Conflict-Affected Countries: The Evolution of a Model (Routledge 2017).

Martii Koskenniemi, 'Hegemonic Regimes' in Margaret Young(ed.) Regime Interaction in International Law: Facing Fragmentation (CUP 2012).

Martii Koskenniemi, The Gentle Civiliser Of Nations: The Rise and Fall Of International Law 1870-1960 (CUP 2001).

Peggy Levitt and Sally Merry, 'making Women's Human Rights in the Vernacular: Navigating the Culture/ Rights Divide' in Dorothy Hodgson (ed.), Gender and Culture at the Limit of Rights (University of Pennsylvania Press 2011).

Scott Newton, 'The Dialectics of Law and Development', in David Trubek and Alvaro Santos (eds.) The New Law and Economic Development: A Critical Appraisal (CUP 2006).

Stephen Humphreys, Theatre of The Rule of Law: Transnational Legal Intervention in Theory and Practice, (CUP 2010).

Thomas Carothers, 'The Rule of Law Revival' in Promoting the Rule Of Law Abroad (Brookings University Press 2010).

Volkmar Gessner and David Nelken(eds.), European Ways of Law: Towards a European Sociology of Law (Bloomsbury Publishing 2007).

Yves Dezaley and Bryant Garth, The Internationalisation of Palace Wars: Lawyers, Economists and the Contest to Transform Latin American States' (The University of Chicago Press 2002). 


\section{Journal Articles}

Adriana Erthal Abdenur and Danilo Marcondes de Souza Neto, 'South- South cooperation and democracy in Africa: Brazil's role in Guinea- Bissau', (2013) 5 (2) Africa Review 104.

Bernard Sapolsky, 'Language Policy in Portuguese Colonies and Successor States', (2018) 19 Current Issues in Language Planning 62.

Clemens Six, 'The Rise of Postcolonial States as Donors: A Challenge to the Development Paradigm?’, (2009) 30 Third World Quarterly 1103.

Cristina Yumi Aoki Inoue and Alcides Costa Vaz, 'Brazil as 'Southern Donor': Beyond Hierarchy and National Interests in Development Cooperation?', (2013) 24 (4) Cambridge Review of International Affairs 507.

Cristina Yumi Inoue and Alcides Costa Vaz, 'Brazil as 'Southern Donor': Beyond 774 Hierarchy and National Interests in Development Cooperation?', (2013) 25 (4) Cambridge Review of International Affairs 507.

Elizabeth Boyle and John Meyer, 'Modern law as a Secularised and Global Model: Implications for the Sociology of Law', (1998) 49 (3) Soziale Welt 213.

Hansjorg Strohmeyer, 'Collapse and Reconstruction of a Judicial System: The United Nations Missions in Kosovo and East Timor', (2000) 95 The American Journal of International Law 46.

IC Leite et.al., 'Brazilian South-South Development Cooperation: The Case of the Ministry of Social Development in Africa' (2015) 27 Journal of International Development 1446.

Kelly Taylor-Leech, 'The Language Situation in Timor- Leste', CURRENT ISSUES IN LANGUAGE PLANNING Vol. 10 (2009)1.

Oliver P. Richmond and Ioannis Tellidis, 'Emerging Actors in International Peacebuilding and Statebuilding: Status Quo or Critical States?', (2014) 20(4) Global Governance 563. 
Paolo de Renzio and Jurek Seifert, 'South- South Cooperation and the Future of Development Assistance: Mapping Actors and Options', (2014) 35 (10) Third World Quarterly 1860.

Sally Merry, 'Measuring the World: Indicators, Human Rights and Global Governance', 2011 52(3) Current Anthropology 83.

Thomas Carothers 'The Rule of law Revival', (1998) 77 (2) Foreign Affairs 95.

\section{Working Papers}

Bruno Pino, 'Brazilian Cooperation: A Model under Construction for an Emerging Power', ( Real Instituto Elcano 2010) < https://www.cbd.int/financial/southsouth/brazil-cooperation.pdf $>$ accessed on 30 May 2019.

C Schläger, 'New powers for global change? Challenges for international development cooperation: the case of Brazil' ( Briefing Papers, no 3, Friedrich Ebert Stiftung, 2007) http://library.fes.de/pdf-files/iez/global/04719.pdf accessed on 30 May 2019.

Kirsti Samuels, 'Rule of Law Reform in Post- Conflict Countries: Operational Initiatives and Lessons Learnt', (2006, Social Development Papers: Conflict Prevention and Reconstruction Paper No. 37).

\section{Websites}

Lindsey Greising and Nelinho Vital, ' Legal Research in Timor-Leste', < http://www.nyulawglobal.org/globalex/Timor_Leste.html\#Courts> accessed on 30 May 2019.

Moises Naim, 'Rogue Aid', (Foreign Policy, 15 October 2009) https://foreignpolicy.com/2009/10/15/rogue-aid/ accessed 30 May 2019.

Mong Palatino, ' East Timor Australia Spying Scandal' ( The Diplomat, 16 December 2013) < https://thediplomat.com/2013/12/east-timor-australia-spyingscandal/> accessed on 30 May 2019. 
Organisation for Economic Co-operation and Development, 'Principles for Good International Engagement in Fragile States' (Development Assistance Committee, Paris 2007) <https://gsdrc.org/document-library/principles-for-good-internationalengagement-in-fragile-states-and-situations/>.

Ricardo Oliveira Dos Santos, ' Developing Countries and UN Peacebuilding: Opportunities and Challenges', (E- International Relations 25 February 2019) < https://www.e-ir.info/2019/02/25/developing-countries-and-un-peacebuildingopportunities-and-challenges/> accessed on 30 May 2019. 